\title{
Effect of Potassium and Sulphur on the Soil Properties, Growth and Yield of Onion (Allium cepa L.) cv. Nasik Red
}

\author{
Marbong* and Narendra Swaroop \\ Department of Soil Science and Agriculture Chemistry, Sam Higginbottom University of \\ Agriculture, Technology and Sciences, Allahabad-211007, Uttar Pradesh, India \\ *Corresponding author
}

\begin{tabular}{|l|}
\hline K e y w o r d s \\
Growth parameters, \\
Onion, Potassium, \\
Soil properties, \\
Sulphur, Bulb yield \\
\hline Article Info \\
\hline $\begin{array}{l}\text { Accepted: } \\
\text { 18 May } 2018 \\
\text { Available Online: } \\
\text { 10 June } 2018\end{array}$ \\
\hline
\end{tabular}

\section{Introduction}

Onion (Allium cepa L.), belongs to family Amaryllidaceae, is the third most important vegetable crop in the world. It is a cool season but can also be grown under a wide range of climatic conditions. The onion plant has hollow leaves and shallow roots. Onion is a very important crop in India and is the $2^{\text {nd }}$ largest producer of onion in the world only next to China. It is grown all over the country across various states like Maharashtra,
Gujarat, Uttar Pradesh, Orissa, Karnataka, Andhra Pradesh, Madhya Pradesh and Bihar which are the major onion growing states in the country. It is cultivated over an area of 1064 thousand hectares with an annual production of 15118 thousand tons but the productivity in India is very low i.e. 14.21 tons $\mathrm{ha}^{-1}$.

Potassium plays an important role on onion production. Generally, a heavy dose of potassium is recommended for onion 
cultivation. Like other tuber and root crops, onion is very responsive to potash. Among all the different types of nutrients which are required to produce a high yield of onion, potassium is considered to be one of the most important element due to its role in the translocation of photosynthates, storage quality, bulb size, and yield per plant. Potassium deficiency in onion is expressed by the appearance of brown tips in older leaves and poor bulb formation. The application of an appropriate quantity and source of $\mathrm{K}$ to onion at critical growth stages is thus essential for maintenance of growth and quality (Subba Rao and Brar, 2002).

The application of sulphur has been found to found not only to increase the bulb yield of onion but also improve its quality, especially pungency and flavors (Jaggi and Dixit, 1999). Bell (1981) also reported sulphur containing secondary compounds was not only of importance for nutritive value and flavors, but also for resistance against pests and diseases. The yield potential of onion has not been exploited fully as the sulphur fertilizer is used in very low quantity instead of its very high requirement. In recent years, sulphur is receiving more attention throughout the world. The deficiency of sulphur in the soil, as a nutrient is increasing in India. Surveys have found that 240 districts to be generally deficient in $\mathrm{S}$ and the problem is spreading (Sakal et al., 1981). A recent effort by the Fertilizer Association of India, The Sulphur Institute and the International Fertilizer Industry Association (FAI-TSI-IFA) studied 27,000 samples distributed over 12 states and found that over $40 \%$ of samples were deficient in available $\mathrm{S}$ and another $35 \%$ potentially deficient. More than $70 \%$ soil samples taken from Uttar Pradesh, Madhya Pradesh, Maharashtra, Orissa, Jharkhand, West Bengal, Andhra Pradesh and Karnataka were low to medium in available S (Biswas et al., 2004). The main reason behind such widespread deficiency are over dependence on "S-free" fertilizers, depletion of $\mathrm{S}$ without continuous cropping, sizable areas (around $27 \%$ of the country's grossed cropped area) under pulses and oilseeds that have higher requirement for $\mathrm{S}$, loss of $\mathrm{S}$ due to leaching, soil erosion, lack of organic manure addition and low awareness of farmers towards use of importance of $S$ in agriculture. Therefore, with these facts in consideration, the present study was carried out to find the effect of potassium and sulphur on the soil properties, response of onion to the bulb yield and plant growth properties and also the economic benefits and profit.

\section{Materials and Methods}

The field experiment to study the effect of potassium and sulphur on onion (Allium cepa L.) was conducted at Research Farm of Soil Science, SHUATS, Allahabad, India. Improved variety of onion, Nasik red, was selected for the study. The soil before the start of the experiment was sandy loam with $\mathrm{pH}$ 7.4, available NPK was 205:23.5:283.4 $\mathrm{kg} \mathrm{ha}^{-1}$ and available $\mathrm{S}$ was $16.8 \mathrm{~kg} \mathrm{ha}^{-1}$, organic carbon $0.50 \%$, electric conductivity $0.41 \mathrm{dSm}^{-}$ 1 , bulk density at $1.30 \mathrm{gm} \mathrm{cm}^{-3}$, particle density at $2.7 \mathrm{gm} \mathrm{cm}^{-3}$ and pore space $51.3 \%$. Two different factors were considered of treatments were considered: (A) Potassium levels $(0,50,100) \mathrm{kg} \mathrm{ha}^{-1}$, (B) Sulphur levels $(0,15,30) \mathrm{kg} \mathrm{ha}^{-1}$. The experiment consisted of 9 treatments and the field was laid out in a Randomized Block Design (RBD) with three replications and treatments were assigned accordingly. Size of each plot was $1 \mathrm{~m}$ x $1 \mathrm{~m}$. The seedlings were transplanted into the plots at a spacing of $20 \times 15 \mathrm{~cm}$. Standard recommended doses of Nitrogen as urea and Phosphorus as DAP (Diammonium Phosphate) were applied across all plots at 100 $\mathrm{kg} \mathrm{ha}^{-1}$ and $50 \mathrm{~kg} \mathrm{ha}^{-1}$ respectively. Potassium was applied as MOP (Muriate of Potash) and Sulphur was applied in the form of elemental sulphur according to the treatment 
combinations which were then applied as a basal dose before transplanting of onion seedlings while Nitrogen was applied at split doses, first after transplanting and the second dose after 30 days of transplanting. Various intercultural operations such as irrigation, weeding, pest control etc. were done uniformly as required. Data from the plants were recorded and observed by selecting and tagging 3 plants at random for each treatment and plant height was observed at 30,60 and 90 days after transplanting (DAT). Bulb height, width and total yield per plot were recorded after harvest. Soil parameters, both physical and chemical, were observed and recorded from each individual plot both before transplanting operations and also after harvest by taking soil at depth of $0-15 \mathrm{~cm}$. The various parameters analysed were $\mathrm{pH}$, organic carbon $\%$, pore space $\%$, bulk and particle density, EC, Nitrogen, Phosphorus, Potassium and Sulphur. The data was then analysed by subjecting it to two way statistical analysis of variance (ANOVA) at $5 \%$ level of probability.

\section{Results and Discussion}

The data in (Table 1) shows the pre-transplant soil data and (Table 2 and 3) shows the analysed statistical data of the various effects of potassium and sulphur doses on the soil properties, growth and yield parameters of onion of which the results are discussed below.

\section{Plant Height}

At all stages of growth of the plant, the treatment combination $\mathrm{T}_{2}\left(\mathrm{~K}\right.$ at $100 \mathrm{~kg} \mathrm{ha}^{-1}$ and $\mathrm{S}$ at $30 \mathrm{~kg} \mathrm{ha}^{-1}$ ), recorded the maximum plant height at $26 \mathrm{~cm}, 45.1 \mathrm{~cm}$ and $60 \mathrm{~cm}$ at 30,60 and 90 DAT respectively, while control treatment recorded the lowest plant height at $8.5 \mathrm{~cm}, 24 \mathrm{~cm}$ and $35 \mathrm{~cm}$ at 30, 60 and 90 DAT respectively. The application of potassium plays an important role in the metabolism and many processes to sustain and promote plant vegetative growth and development and also plays a major role in cell division and elongation and metabolism and synthesis of carbohydrates and protein compounds. The increase in plant height due to increasing levels of potassium were also observed and recorded by Abou El-Nasr and Ibrahim (2011), Shafeek et al., (2013) and Awatef G. Behairy et al., (2015). Higher dosage of sulphur also showed significant increase in plant height across all stages of crop growth. The increase in plant might be due to the role of sulphur in the synthesis of chloroplast. M. H. A. Rashid (2010), R. Meher et al., (2016) and P. Tripathy et al., (2013) also reported similar results of increase in plant height of onion with increasing levels of sulphur.

\section{Bulb length and diameter}

The bulb length and diameter of the bulbs showed significant increase with higher levels of potassium and sulphur. The treatment combination $\mathrm{T}_{2}\left(\mathrm{~K}\right.$ at $100 \mathrm{~kg} \mathrm{ha}^{-1}$ and $\mathrm{S}$ at 30 $\mathrm{kg} \mathrm{ha}^{-1}$ ) gave the highest results at $6.1 \mathrm{~cm}$ and $8.7 \mathrm{~cm}$ for bulb length and diameter respectively. It is due to the fact that potassium isvery important for the overall metabolism of plant enzyme activity and it was found to serve a vital role in photosynthesis by directly increasing the growth ofthe bulb. Also, potassium has a beneficial effect on water consumption (Mansour, 2006). Similar resultswere also observed by Awatef G. Behairy et al., (2015) and M.K. Ali et al., (2007).

Sulphur application also play and important role in determining the shape and size of onion bulb. More efficient $S$ utilization resulted in greater increases in bulb length (Abbey et al., 2002). These results are in accordance with Nagaich et al., (1999) and Tripathy et al., (2013) who also reported similar findings. 


\section{Total yield of onion bulbs}

Potassium application at higher doses showed significant increase in total yield of onion. This could be due to the fact that potassium plays a very important role in photosynthesis by increasing the overall metabolism of plant enzyme activity which shows the direct increase in growth and bulb yield. Similar results were observed by Shah Saud et al., (2013).

Sulphur increases the uptake of N, P, K and S by the plant which might lead to enhanced synthesis and translocation of photosynthates to the bulbs and hence increase the overall total yield. Similar results on the total yield of onion due to increasing levels of sulphur were also observed by R. Meher et al., (2016) and R. F. Channagoudar and A. D. Janawade (2006). The treatment combination $\mathrm{T}_{2}(\mathrm{~K}$ at $100 \mathrm{~kg} \mathrm{ha}^{-1}$ and $\mathrm{S}$ at $30 \mathrm{~kg} \mathrm{ha}^{-1}$ ) had the highest yield total bulb at 13.55 tons ha ${ }^{-1}$.

\section{Bulk and particle density and pore space of soil}

The bulk density and particle density of the soil after crop harvest decreased as a result of increased dosage of potassium and sulphur which might be due to the fact that that onion is a bulb crop and it loosens the soil when it is grows in the soil thereby improving soil structure and increasing the availability of certain plant nutrients in soil, which in turn showed an increase in the pore space percentage in the soil compared to the soil data before transplanting, This results were also reported by R. Pradhan et al., (2014).

\section{Soil organic carbon}

The organic carbon content in the soil showed a significantly slight decrease with increasing dosage of potassium and sulphur which might be attributed to the fact that plants used the organic carbon present for their growth and development and also because more inorganic materials were added rather than organic fertilizers and due to lack of the addition of FYM. This was also reported by P. K. Basavaraja et al., (2007).

\section{Soil pH}

The soil $\mathrm{pH}$ showed a significant drop after crop harvest with increasing dosage of potassium and sulphur. The initial $\mathrm{pH}$ value of the soil before transplanting operations was done was observed to be at 7.4 and the application of $\mathrm{K}$ at $100 \mathrm{~kg} \mathrm{ha}^{-1}$ and $\mathrm{S}$ at $30 \mathrm{~kg}$ $\mathrm{ha}^{-1}$ showed $\mathrm{pH}$ value of 7.07 after harvest. The decrease in $\mathrm{pH}$ can be due to the fact that with higher application of potassium and sulphur, it increases the overall metabolism of the plant and photosynthesis and respiration. Respiration in plants changes the carbon dioxide and reacts with water with water to form carbonic acid in the soil. This was also reported by R. Pradhan et al., (2014).

\section{Electric conductivity of soil}

The EC value of the soil did show a slight decrease after harvest but the results were found to be non-significant and the addition of different levels of potassium and sulphur showed no particular effects.

\section{Available NPK and Sulphur in soil}

The available values of NPK along with sulphur in the soil after harvesting showed a gradual decrease significantly with increasing dosage on potassium and sulphur. Nitrogen levels were lowest in the treatment combination $\mathrm{T}_{2}\left(\mathrm{~K}\right.$ at $100 \mathrm{~kg} \mathrm{ha}^{-1}$ and $\mathrm{S}$ at 30 $\mathrm{kg} \mathrm{ha}^{-1}$ ) at $95.50 \mathrm{~kg} \mathrm{ha}^{-1}$ and highest in control at $107.25 \mathrm{~kg} \mathrm{ha}^{-1}$. Compared to the soil sample data before transplanting at $205 \mathrm{~kg} \mathrm{ha}^{-1}$, the amount of nitrogen had decreased significantly. 
Table.1 Initial status of the soil before transplanting and growth of onion

\begin{tabular}{|c|c|}
\hline Parameters & Results \\
\hline Texture of the soil & Sandy Loam \\
\hline Bulk density $\left(\mathrm{gm} / \mathrm{cm}^{3}\right)$ & 1.30 \\
\hline Particle density $\left(\mathrm{gm} / \mathrm{cm}^{3}\right)$ & 2.7 \\
\hline Pore space (\%) & 51.3 \\
\hline Soil pH & 7.4 \\
\hline$E C\left(d_{S m}^{-1}\right)$ & 0.41 \\
\hline OC (\%) & 0.50 \\
\hline A vailable $\mathbf{N}\left(\mathrm{Kg} \mathrm{ha}^{-1}\right)$ & 205 \\
\hline A vailable $\mathrm{P}\left(\mathrm{Kg} \mathrm{ha}^{-1}\right)$ & 23.5 \\
\hline Available $\mathrm{K}\left(\mathrm{Kg} \mathrm{ha}^{-1}\right)$ & 283.4 \\
\hline Available $\mathrm{S}\left(\mathrm{Kg} \mathrm{ha}^{-1}\right)$ & 16.8 \\
\hline
\end{tabular}

Table.2 Effect of different levels of Potassium and Sulphur on growth parameters and yield of Onion

\begin{tabular}{|c|c|c|c|c|}
\hline Treatment dosage & $\begin{array}{l}\text { Plant } \\
\text { height } \\
\text { (cm) }\end{array}$ & $\begin{array}{l}\text { Bulb width } \\
(\mathrm{cm})\end{array}$ & $\begin{array}{l}\text { Bulb length } \\
(\mathrm{cm})\end{array}$ & $\begin{array}{l}\text { Bulb yield } \\
\left(\text { tons } \mathrm{ha}^{-1} \text { ) }\right.\end{array}$ \\
\hline $\begin{array}{l}T_{1}\left(\mathrm{~K} \text { at } 50 \mathrm{~kg} \mathrm{ha}^{-1}\right. \\
\left.\text { S at } 15 \mathrm{~kg} \mathrm{ha}^{-1}\right) \\
\end{array}$ & 58.07 & 5.2 & 4.5 & 8.15 \\
\hline $\begin{array}{l}T_{2}\left(\mathrm{~K} \text { at } 100 \mathrm{~kg} \mathrm{ha}^{-1}\right. \\
\left.\mathrm{S} \text { at } 30 \mathrm{~kg} \mathrm{ha}^{-1}\right)\end{array}$ & 60.60 & 8.7 & 6.1 & 13.55 \\
\hline $\begin{array}{l}\mathrm{T}_{3}\left(\mathrm{~K} \text { at } 50 \mathrm{~kg} \mathrm{ha}^{-1}\right. \\
\left.\text { S at } 30 \mathrm{~kg} \mathrm{ha}^{-1}\right) \\
\end{array}$ & 58.50 & 6.8 & 5.5 & 10.1 \\
\hline $\begin{array}{l}\mathrm{T}_{4}\left(\mathrm{~K} \text { at } 50 \mathrm{~kg} \mathrm{ha}^{-1}\right. \\
\left.\mathrm{S} \text { at } 0 \mathrm{~kg} \mathrm{ha}^{-1}\right)\end{array}$ & 53 & 5.8 & 4.5 & 8.55 \\
\hline $\begin{array}{l}\mathrm{T}_{5}\left(\mathrm{~K} \text { at } 100 \mathrm{~kg} \mathrm{ha}^{-1}\right. \\
\left.\mathrm{S} \text { at } 15 \mathrm{~kg} \mathrm{ha}^{-1}\right) \\
\end{array}$ & 55.47 & 7.5 & 4.7 & 9.05 \\
\hline 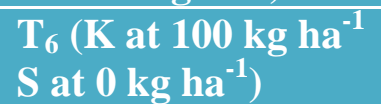 & 54.40 & 6.2 & 5.4 & 8.92 \\
\hline 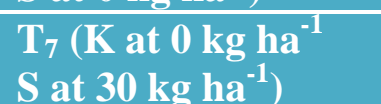 & 55.50 & 5.2 & 4.8 & 7.64 \\
\hline $\begin{array}{l}\mathrm{T}_{8}\left(\mathrm{~K} \text { at } 0 \mathrm{~kg} \mathrm{ha}^{-1}\right. \\
\left.\text { S at } 15 \mathrm{~kg} \mathrm{ha}^{-1}\right)\end{array}$ & 56.60 & 5.0 & 4.3 & 7.82 \\
\hline $\mathrm{T}_{\mathbf{0}}$ (Control) & 43 & 4.5 & 3.9 & 6.38 \\
\hline F-Test & $\mathbf{S}$ & $\mathbf{S}$ & $\mathbf{S}$ & $\mathbf{S}$ \\
\hline SE. $d( \pm)$ & 4.08 & 0.21 & 0.19 & 1.18 \\
\hline C.D. at 5\% & 8.66 & 0.44 & 0.41 & 2.51 \\
\hline
\end{tabular}


Table.3 Effect of different levels of Potassium and Sulphur on soil properties (physical and chemical) after harvest of onion

\begin{tabular}{|c|c|c|c|c|c|c|c|c|c|c|}
\hline $\begin{array}{l}\text { Treatment } \\
\text { dosage }\end{array}$ & $\begin{array}{l}\text { Bulk } \\
\text { Density } \\
\left(\mathrm{gm} / \mathrm{cm}^{3}\right)\end{array}$ & $\begin{array}{l}\text { Particle } \\
\text { Density } \\
\left(\mathrm{gm} / \mathrm{cm}^{3}\right)\end{array}$ & $\begin{array}{l}\text { Pore } \\
\text { Space } \\
(\%)\end{array}$ & $\begin{array}{l}\mathrm{OC} \\
(\%)\end{array}$ & $\mathrm{pH}$ & $\begin{array}{l}\mathrm{EC} \\
\text { (dSm } \\
\text { 1) }\end{array}$ & $\begin{array}{l}\mathbf{N} \\
(\mathbf{k g ~ h a} \\
\left.{ }^{1}\right)\end{array}$ & $\begin{array}{l}\text { P } \\
(\mathrm{kg} \\
\left.\mathrm{ha}^{-1}\right)\end{array}$ & $\begin{array}{l}\text { K } \\
(\mathbf{k g ~ h a} \\
1 \text { ) }\end{array}$ & $\begin{array}{l}\mathrm{S} \\
\left(\mathrm{kg}^{-1}\right. \\
\left.\mathrm{ha}^{-1}\right)\end{array}$ \\
\hline $\begin{array}{l}\mathrm{T}_{1}\left(\mathrm{~K} \text { at } 50 \mathrm{~kg} \mathrm{ha}^{-}\right. \\
\left.\mathrm{S} \text { at } 15 \mathrm{~kg} \mathrm{ha}^{-1}\right)\end{array}$ & 1.14 & 2.58 & 53.31 & 0.47 & 7.23 & 0.36 & 102 & 17.3 & 256.30 & 13.92 \\
\hline $\begin{array}{l}\mathrm{T}_{2}(\mathrm{~K} \text { at } 100 \mathrm{~kg} \\
\mathrm{ha}^{-1} \\
\left.\mathrm{~S} \text { at } 30 \mathrm{~kg} \mathrm{ha}^{-1}\right)\end{array}$ & 1.13 & 2.67 & 56.95 & 0.45 & 7.07 & 0.35 & 95.50 & 15.07 & 241.80 & 13.20 \\
\hline $\begin{array}{l}\mathrm{T}_{3}\left(\mathrm{~K} \text { at } 50 \mathrm{~kg} \mathrm{ha}^{-}\right. \\
\left.\mathrm{S} \text { at } 30 \mathrm{~kg} \mathrm{ha}^{-1}\right)\end{array}$ & 1.15 & 2.59 & 54.59 & 0.44 & 7.17 & 0.38 & 99.75 & 17.43 & 261.60 & 14.98 \\
\hline $\begin{array}{l}\mathrm{T}_{4}\left(\mathrm{~K} \text { at } 50 \mathrm{~kg} \mathrm{ha}^{-}\right. \\
\left.\text {S at } 0 \mathrm{~kg} \mathrm{ha}^{-1}\right)\end{array}$ & 1.15 & 2.62 & 53.59 & 0.46 & 7.15 & 0.37 & 102.75 & 17.93 & 267.10 & 15.19 \\
\hline $\begin{array}{l}T_{5}(\mathrm{~K} \text { at } 100 \mathrm{~kg} \\
\mathrm{ha}^{-1} \\
\left.\text { S at } 15 \mathrm{~kg} \mathrm{ha}^{-1}\right) \\
\end{array}$ & 1.15 & 2.61 & 53.98 & 0.45 & 7.30 & 0.36 & 100.50 & 18.57 & 270.40 & 14.93 \\
\hline $\begin{array}{l}\mathrm{T}_{6}(\mathrm{~K} \text { at } 100 \mathrm{~kg} \\
\mathrm{ha}^{-1} \\
\left.\mathrm{~S} \text { at } 0 \mathrm{~kg} \mathrm{ha}^{-1}\right) \\
\end{array}$ & 1.18 & 2.65 & 54.32 & 0.45 & 7.27 & 0.37 & 101.25 & 20.27 & 266.80 & 13.80 \\
\hline $\begin{array}{l}\mathrm{T}_{7}\left(\mathrm{~K} \text { at } 0 \mathrm{~kg} \mathrm{ha}^{-1}\right. \\
\left.\text { S at } 30 \mathrm{~kg} \mathrm{ha}^{-1}\right)\end{array}$ & 1.17 & 2.59 & 52.66 & 0.47 & 7.30 & 0.36 & 105.75 & 17.30 & 249.53 & 14.34 \\
\hline $\begin{array}{l}\mathrm{T}_{8}\left(\mathrm{~K} \text { at } 0 \mathrm{~kg} \mathrm{ha}^{-1}\right. \\
\left.\mathrm{S} \text { at } 15 \mathrm{~kg} \mathrm{ha}^{-1}\right)\end{array}$ & 1.17 & 2.62 & 52.51 & 0.46 & 7.27 & 0.36 & 102.75 & 21.27 & 265.20 & 14.91 \\
\hline $\mathrm{T}_{0}$ (Control) & 1.22 & 2.54 & 51.68 & 0.46 & 7.33 & 0.38 & 107.25 & 22.60 & 276.00 & 15.62 \\
\hline F-Test & $\mathbf{S}$ & $\mathbf{S}$ & $\mathbf{S}$ & $\mathbf{S}$ & $\mathbf{S}$ & NS & $\mathbf{S}$ & $\mathbf{S}$ & $\mathbf{S}$ & $\mathbf{S}$ \\
\hline SE. $d( \pm)$ & 0.01 & 0.07 & 1.92 & 0.02 & 0.09 & 0.005 & 5.11 & 1.26 & 4.35 & 0.58 \\
\hline C.D. at 5\% & 0.03 & 0.14 & 4.08 & 0.04 & 0.19 & 0.03 & 10.83 & 2.67 & 9.21 & 1.26 \\
\hline
\end{tabular}

The increased uptake of nitrogen can be attributed to the increased dry matter production and usage by the plant for its development. Higher levels of sulphur also influenced nitrogen uptake by the plant which may have influenced the synthesis and translocation of the stored materials. Increased uptake of nitrogen due to higher doses of potassium application was also reported by Girigowda et al., (2005) and Shafeek et al., (2013). Effect of sulphur on nitrogen uptake by onion plant was reported by R. Pradhan et al., (2014).

Similiar trends of were observed in phosphorus, potassium and sulphur values in the soil after harvest along with increasing dosage of potassium and sulphur. Available phosphorus values went down from $23.5 \mathrm{~kg}$ $\mathrm{ha}^{-1}$ before transplanting to $15.07 \mathrm{~kg} \mathrm{ha}^{-1}$ atthe treatment combination of $\mathrm{T}_{2}\left(\mathrm{~K}\right.$ at $100 \mathrm{~kg} \mathrm{ha}^{-1}$ and $\mathrm{S}$ at $30 \mathrm{~kg} \mathrm{ha}^{-1}$ ). The decrease in 
phosphorus may be attributed due to plant uptake of phosphorus as immobilization as a result of increased microbial activity which was reported by Emmanuel Kwada Kwaghe et al., (2017).

The application of increasing levels of sulphur shows the increased intake of potassium by the onion plant significantly which indicates the synergistic effect of sulphur on potassium nutrition in onion. The treatment combination of $\mathrm{T}_{2}\left(\mathrm{~K}\right.$ at $100 \mathrm{~kg} \mathrm{ha}^{-1}$ and $\mathrm{S}$ at $30 \mathrm{~kg} \mathrm{ha}^{-1}$ ) showed available potassium values at $241.80 \mathrm{~kg} \mathrm{ha}^{-1}$ compared to pre-transplant soil data at $283.4 \mathrm{~kg} \mathrm{ha}^{-1}$. This is due to the greater vegetative growth, translocation of stored material and bulb production. This was observed and reported by R. Pradhan et al., (2014) and Jaggi (2005).

The decrease of sulphur content in the soil was also observed due to the increased uptake of sulphur by the plant. Again the treatment combination of $\mathrm{T}_{2}\left(\mathrm{~K}\right.$ at $100 \mathrm{~kg} \mathrm{ha}^{-1}$ and $\mathrm{S}$ at $30 \mathrm{~kg} \mathrm{ha}^{-1}$ ) showed the lowest amount of available sulphur in the soil after harvest at $13.20 \mathrm{~kg} \mathrm{ha}^{-1}$ comparing to the amount of $16.8 \mathrm{~kg} \mathrm{ha}^{-1}$ before transplanting operations. This is because increasing dosage of both potassium and sulphur increases the metabolism and nutrient uptake of the plants which leads to increased uptake of sulphur from the soil by the plants. These results are in accordance with the findings of R. Pradhan et al., (2014), Dabhi et al., (2004) and Jaggi (2005).

Based on the above results and data collected and observed, it is concluded that the application of potassium and sulphur at 100 $\mathrm{kg} \mathrm{ha}{ }^{-1}$ and $30 \mathrm{~kg} \mathrm{ha}^{-1}$ showed the most beneficial and significant increase in growth parameters and total bulb yield of Onion grown under Allahabad agro-climatic conditions while also providing the maximum gross return, net profit and Cost: Benefit ratio.
It also significantly improved the soil physical soil structure properties but showed a significant decrease in amount of available nutrients in the soil after harvest. Although this may be due to the fact that the increasing amount of dosage of potassium and sulphur aids the plant to grow healthier, which leads to the increased uptake of nutrients, the residual nutrient amount in the soil is very important for sustainability. As such, properties of the soil like soil organic carbon content could be increased with addition of organic fertilizers like FYM or also using biofertilizers along with ideal dosage of fertilizers. Nitrogen can also be replenished with the rotation of crops after onion harvest with the planting of leguminous crops which will cycle nitrogen back into the soil. As such, these findings are based on one year research trial, to sustain more work to be needed for the same.

\section{References}

Abou El-Nasr, M. E. and E. A. Ibrahim (2011) Effect of different potassium fertilizer rates and foliar application with some sources of potassium on growth, yield and quality of carrot plants (Daucus carota L.) J. Plant Production, Mansoura Univ., Vol. 2 (4): $559-569$.

Ali, M.K., M.F. Alam, M.N. Alam, M.S. Islam and S.M.A.T. Khandaker (2007) Effect of nitrogen and potassium level on yield and quality seed production of onion, Journal of Applied Sciences Research, 3(12): 18891899.

Awatef G. Behairy, Asmaa R. Mahmoud, M.R. Shafeek, Aisha H. Ali and Magda M. Hafez (2015) Middle East Journal of Agriculture Research Volume : 4 | Issue : 01 | Jan-Mar. | 2015 Pages: 60-66.

Basavaraja, P. K., S. Sridhara, A. R. Sushma and G. R. Hareesh (2007) Effect of integrated nutrient management on onion yield and soil properties under Chromic Haplusterts of Karnataka J. Hort. Sci. Vol. 2 (1): 34-37. 
Bell. A. A. 1981. Biochemical mechanism of disease resistance. Ann. Rev. Plant. Physio, 32: 21-81.

Biswas, B.C., et al., (2004). Fert. News, 49(10), p. $13-33$.

Channagoudar, R. F., and A. D. Janawade (2006) Effect of Different Levels of Irrigation and Sulphur on Growth, Yield and Quality of Onion (Allium cepa L.) Karnataka J. Agric. Sci., 19(3): (489-492).

Dabhi, N. M., Patel, M. V. and Patel, V. R. (2004).Effect of sources and levels of sulphur on yield and chemical composition of onion in loamy sand. National Seminar on Development in Soil Science: $69^{\text {th }}$ Annual Convention, Hyderabad, October 27-30, P. 124.

Emmanuel Kwada Kwaghe, Abdullahi Muhammad Saddiq, Rejoice Ibrahim Solomon, Salihu Ardo Musa (2017). Integrated nutrient management on soil properties and nutrient uptake by red onion. Turkish Journal of Agriculture - Food Science and Technology, 5(5): 471-475.

Girigowda, J. R., Narasegowda, N. C. and Krishna, H. C., (2005), Effect of fertilizer levels on uptake of primary nutrients and bulb yield of onion hybrids. Mysore J. Agric. Sci. 39(4): 557 - 560.

Jaggi, R. C. and S. P. Dixit, 1999.Onion responses to sulphur in representative vegetable growing soils Kangra Valley of Himachal Pradesh.Indian J. Agri. Sci. 69289-291.

Jaggi, R. C., (2005). Sulphur levels and sources affecting yield and yield attributes in onion (Allium cepa). Indian J. Agric. Sci., 75(3): $154-156$.

Meher, R., J. Mandal, D. Saha and S. Mohanta (2016) Effect of sulphur application in onion (Allium cepa L.) Journal of Crop and Weed, 12(3):86-90.

Nagaich, K. N., Tridevi, S. K. and Fajesh Lekhi, (1998), Effect of sulphur and potassium. fertilization on onion (Allium cepa L.). South Indian Hort., 46(5 \& 6): $266-271$.

Pradhan, R., A. K. Pattnaik, P. Tripathy, K. Mallikarjunarao, B. B. Sahoo and J. Lenka (2015) Influence of sulphur fertilization on nutrient uptake of onion (Allium cepa L.) Journal Crop and Weed, 11(Special Issue):134-138.

Rashid, M. H. A., (2010) Effect of sulphur and $\mathrm{GA}_{3}$ on the growth and yield of onion.Progress. Agric. 21(1 \& 2): 57 - 63, 2010.

Sakal, R., et al., 1981. Madras Agric. J. 68, 343

Shafeek, M.R., Nagwa, M.K. Hassan, S. M.Singer and Nadia H. M. EL-Greadly (2013) Effect of potassium fertilizer and foliar spraying with etherel on plant development, yield and bulb quality of onion plants (Allium cepa L). Journal of Applied Sciences Research, 9(2): 1140-1146.

Shah Saud, Chun Yajun, Muhammad Razaq, Muhammad Luqman, Shah Fahad, Muhammad Abdullah and AroojSadiq (2013) Growth, yield and bulb quality of onion Plants (Allium cepa L.) as affected by foliar and soil application of potassium. Journal of Biology, Agriculture and Healthcare ISSN 2224-3208 (Paper) ISSN 2225-093X (Online) Vol.3, No.16, 2013.

Subba Rao, A. and Brar, M.S. (2002). Potassium. In Fundamentals of Soil Science. Indian Soc of Soil Sci. 1ARI, New Delhi. P. 369380.

Tripathy, P., B. B. Sahoo, A. Priyadarshini, S.K. Das and D. K. Dash (2013) Effect of sources and levels of sulphur on growth, yield and bulb quality in onion (Allium cepa L.) International Journal of Bio-resource and Stress Management 2013, 4(4):641644.

\section{How to cite this article:}

Marbong and Narendra Swaroop. 2018. Effect of Potassium and Sulphur on the Soil Properties, Growth and Yield of Onion (Allium cepa L.) cv. Nasik Red. Int.J.Curr.Microbiol.App.Sci. 7(06): 1584-1591. doi: https://doi.org/10.20546/ijcmas.2018.706.189 